DOI : 10.33451/florafauna.v26i1pp03-10

FLORA AND FAUNA

ISSN 2456 - 9364 (Online)

2020 Vol. 26 No. 1 PP 03-10

ISSN 0971 - 6920 (Print)

\title{
Nag Tibba the Beauty trail of lesser Himalayas of Uttarakhand with special reference to fauna and flora conservation
}

*Rajeev Shankhwar', Vijay Vardhan Pandey² and Abhishek Yadav ${ }^{1}$

\author{
${ }^{1}$ Division of Genetics \& Tree Improvement, \\ ${ }^{2}$ Division of Forest Pathology, \\ Forest Research Institute, \\ DEHRADUN-248006 (UTTARAKHAND) INDIA \\ ${ }^{*}$ Corresponding Author \\ Email : 1986sergent@gmail.com
}

Received : 25.03.2020; Revised : 28.04.2020; Accepted : 01.05.2020

\section{ABSTRACT}

Fauna and flora is one of the principal components for any region and acts mutually to sustain the forest ecology, food chain as well as local climate. If fauna faces any stress and conflict by anthropomorphic pressures, so simultaneaesly effects the flora. The adverse consequences by tourist and trekkers in the Nag Tibba regions, especially for fauna. The importance of Tag Tibba region wild life as well as local forest free species and their uses are described.

Figures : $05 \quad$ References : $35 \quad$ Table : 00

KEY WORDS : FSI, ISFR, Nag Tibba tap, Reptiles

\section{Introduction}

Nag Tibba is distinguished for its majestic beauty, an abundance of fauna and flora, picturesque view of the great Himalayas from Nag Tibba top and the ideal place for the nature lover and the beginner trekkers. Nag Tibba located in Lesser Himalayas, a north-west part from Badrigad range, Mussoorie forest division at the altitude of $3022.09 \mathrm{~m}$ and its lies between $30^{\circ} 35^{\prime} 13.53^{\prime \prime} \mathrm{N}$ latitude to $78^{\circ} 9^{\prime} 2.95 " E$ longitude. The Nag Devta temple location is $30^{\circ} 35^{\prime} 9.14^{\prime \prime} \mathrm{N}, 78^{\circ} 8^{\prime} 29.68^{\prime \prime} \mathrm{E}$, and the Camping site locate in $30^{\circ} 35^{\prime} 18.55^{\prime \prime} \mathrm{N}, 78^{\circ} 7^{\prime} 14.00^{\prime \prime} \mathrm{E}$, latitude and longitude respectively. Nag Tibba is not only famous for trekking but also famous for the Nag Devta (Snake God) temple. Villagers believe, that worship of Nag Devta will protect their cattle from snake bites. The best time to trek and camping in Nag Tibba is spring, summer and winter session, but most of time nature lover prefers winter session because in winter, high altitude treks in Uttarakhand, covered with heavy snow, which causes amateur trekker prefers easy accessible Tag Tibba trek. There are several ways to go Nag Tibba for trekking and camping. Nature lovers/ tourist can come through Vikas Nagar (Dehradun District) if they are coming from Haryana, Punjab, and Himachal Pradesh state and tourist belongs to other states can go Nag Tibba via by Dehradun, Mussoorie. There are three villages, Devalsari, Manglori and Pantwari from where trekker can start the trek. Usually, trekkers prefer Pantwari village for trekking because this trek covers around $8 \mathrm{~km}$ and rest of two villages treks cover 10-12 km with high incline, which increases more challenges and takes more time to reach the top of Nag Tibba compared to Pantwari village trek. Pantwari is the village where trekkers pack their bag and buy snacks and prepare food from local shopkeepers for the trekking. The charcoal road is accessible only at Pantwari village, after that 3-4 km rough (un-metal) motor road available toward Nag Tibba trek.

From the top of Nag Tibba, an unobstructed panorama view of Himalaya's mountain ranges witness in the morning time (before 10-11 am) because after that cloud and fog, cover the entire Himalaya mountain range. From west to east separate peaks and ranges are visible, in which some clear distinguished peaks and ranges are Bandarpunch mountain range, Kalanag or Black Peak $6387 \mathrm{~m}$, Swargarohini 6252m (Bandarpunch mountain range), Gangotri-I 6672m and Chaukhamba 7138m in the Gangotri Group of the Garhwal Himalaya.

\section{Forest covers density in Nag Tibba region}

Forest Survey of India (FSI) publishes State of Forest Report (ISFR), in which FSI produces forest cover map in three classes ${ }^{4,5}$. Very dense forest (VDF), include tree canopy cover density of $70 \%$ and above. Moderately dense forest (MDF), include tree canopy cover density $40 \%$ and more but smaller than $70 \%$ and Open forest (OF), include tree canopy cover density of $10 \%$ and more but less than $40 \%$. In the current article, we generated 2 $\mathrm{km}^{2}$ buffer zone of the trek for showing forest cover under Nag Tibba region. Total $233 \mathrm{~km}^{2}$ area of forest cover calculated in $2 \mathrm{~km}^{2}$ buffer zone, in which VDF is 11.80 $\mathrm{km}^{2}, \mathrm{MDF}$ is $12.08 \mathrm{~km}^{2}$ and OF is $4.24 \mathrm{~km}^{2}$ (source 


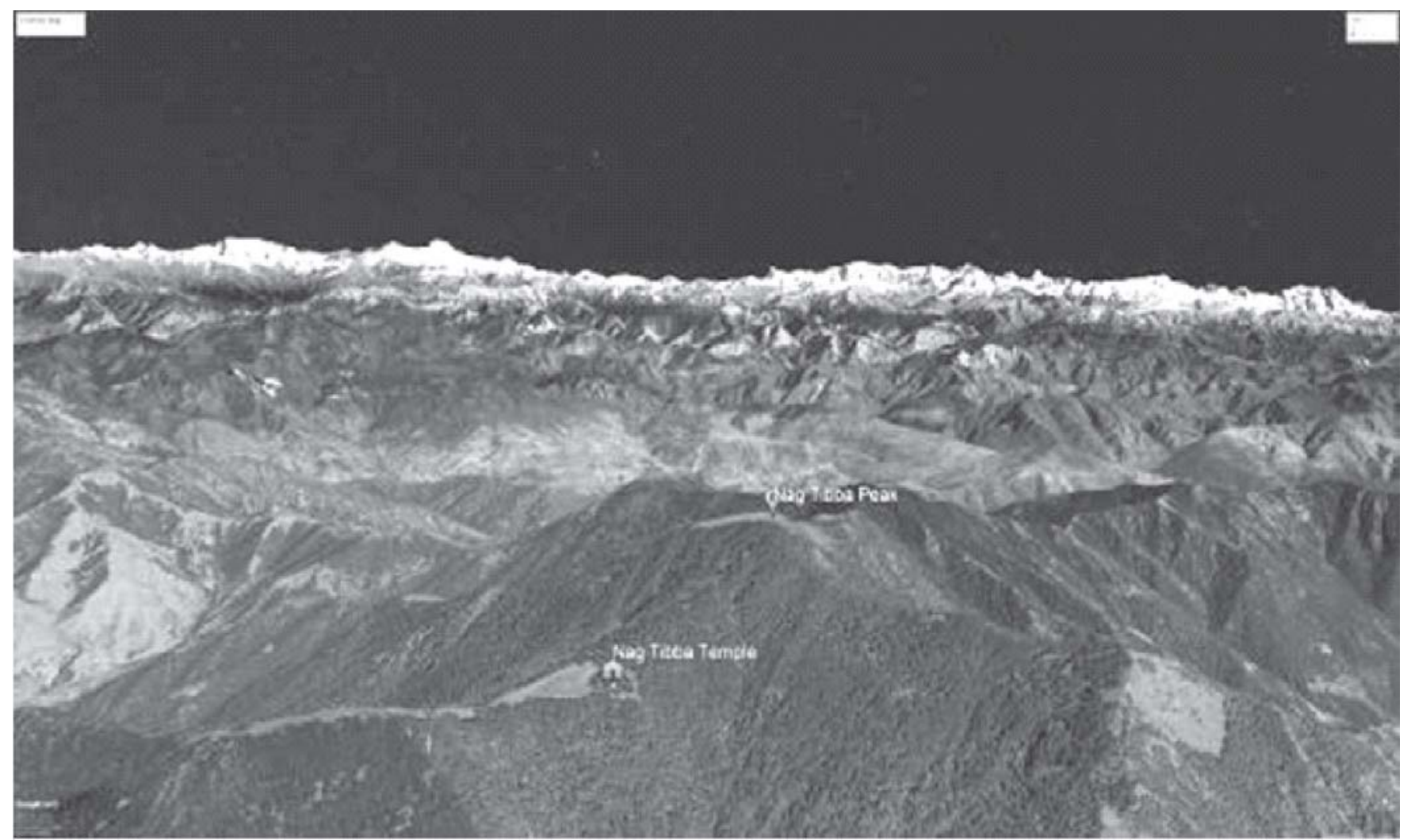

Fig. 1 : Location of Nag Tibba Temple, Peak of Nab Tibba and view of great Himalayas Range and peaks (*Source of Fig: - Google Earth Pro version 7.3.2.5776)

\section{ISFR 2019, FSI).}

\section{Forest types in Nag Tibba region}

Forest types in Nag Tibba region, according to Forest types Atlas ${ }^{4}$, are $12 / \mathrm{C} 1$ b Moru Oak Forest (Q.dilatata) $8.81 \mathrm{~km}^{2}, 12 / \mathrm{C} 1$ a Ban Oak Forest (Q.incana) $2.76 \mathrm{~km}^{2}, 9 / \mathrm{C} 1 \mathrm{~b}$ Upper or Himalayan Chir Pine Forest $9.56 \mathrm{~km}^{2}, 12 / \mathrm{C} 2 \mathrm{~b}$ West Himalayan upper Oak/fir Forest $6.14 \mathrm{~km}^{2}$ and $12 / 1 \mathrm{~S} 1$ Alder Forest $0.08 \mathrm{~km}^{2}$.

\section{Observed local species during the trekking}

During the trek to Nag Tibba Top, we explored some local tree species as well as climate indicator tree species from the beginning of the trek about $1400 \mathrm{~m}$ altitude, first important species we recognized is Grewia optiva, Toona ciliata and Prunus persica spread on the outer boundary of agriculture field. After reach to $1500 \mathrm{~m}$, moderate to the dense forest, Quercus leucotrichophora (Bhanj-oak) forest start with Myrica esculenta (Khafal) and lyonia ovalifolia (Ayaar), spread under the canopy cover of Quercus leucotrichophora. Between 2350 to 2400m, we observed Quercus semecarpifolia and Rhododendron arboreum dense forest, and northwest aspect, near the Nag Tibba temple; we also distinguish Taxus baccata small and seedling trees.

\section{Fauna and flora found in Nag Tibba Region \\ Flora}

\section{Celtis australis}

Celtis australis (khark, khirk) is a medium to a large-sized deciduous tree with the straight stem up to $25 \mathrm{~m}$ tall. In western Himalaya forests, normally it's grown in association with horse chestnut and oak in moist localities. Leaves of $C$. australis is used as fodder, fiber extract from the inner layer of bark used to make rope and mats, the wood used for poles and other household work. Extracts obtained from the tree is used as a vermifuge. Extracts from the tree also used to treat oedema, headache and boils ${ }^{20}$.

\section{Grewia optiva}

Grewia optiva (Bhimal) is a medium-sized deciduous tree about to 9-12 $\mathrm{m}$ in height (URL1) found near agriculture fields. Normally the tree is cut down during winters for fodder, Branches of the tree are cut during the winter season and dipped in water for a month and the soaked branches are beaten and fiber is extracted for making ropes. Women also use their bark extract for hair wash and treating for dandruff (URL 2).

\section{Rhododendron arboreum}

Rhododendron arboreum (Burans) is an evergreen 


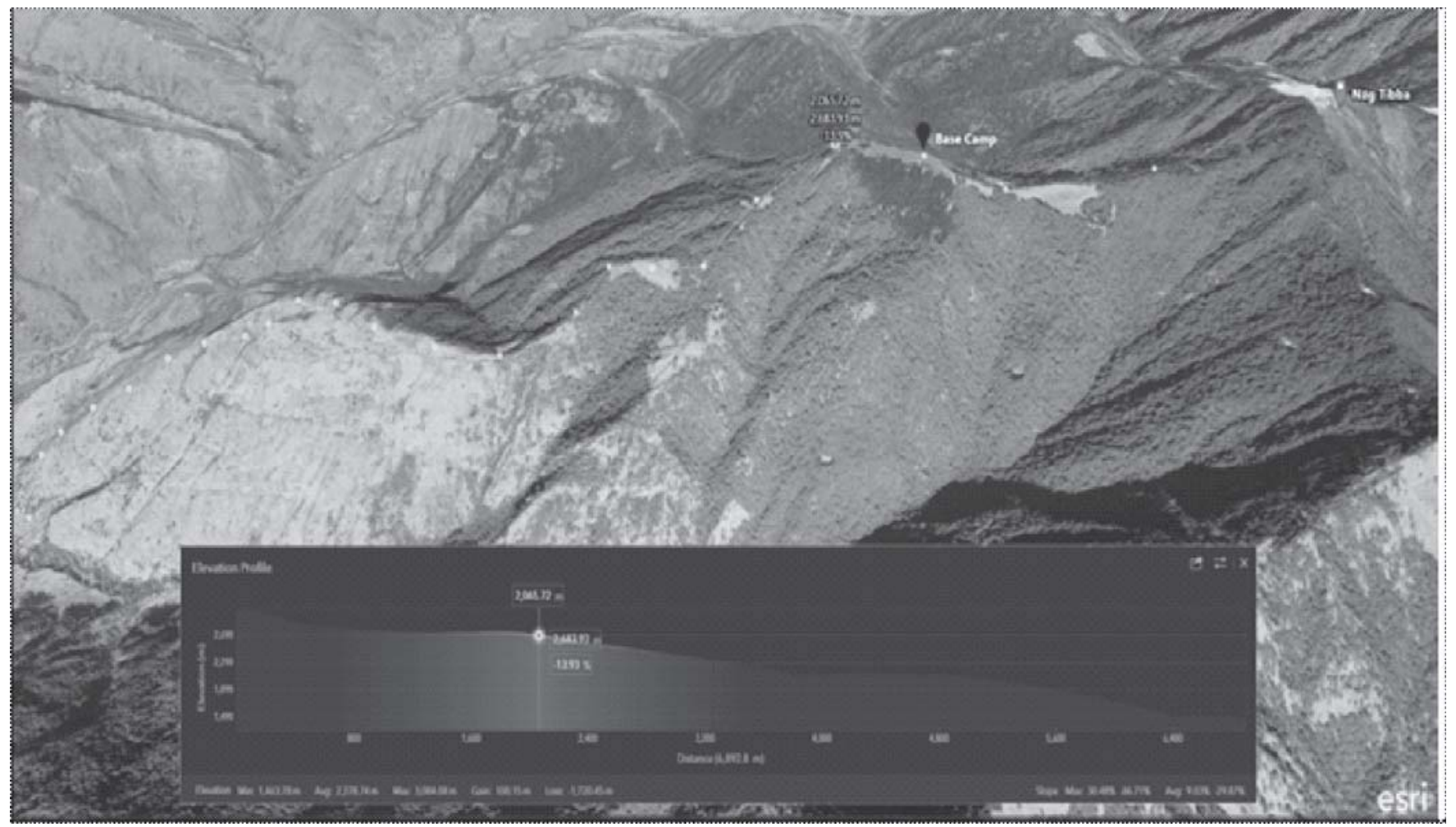

Fig. 2 : Elevation Profile Nag Tibba trek, (Source of Fig: - ESRI, ArcGIS earth, version 1.9)

dense canopy tree height up to $14 \mathrm{~m}$ with approx $2.4 \mathrm{~m}$ in girth $^{1}$. R. arboreum is the state tree of Uttarakhand, every part of $R$. arboreum has medical properties like Flower (anti-diabetic, antimicrobial activity, anti-inflammatory), leaves (Antioxidant activity, anti-inflammatory), root(Anticancer), bark (Excellent cold reliever, antimicrobial agent) and stem (Hemorrhage, hay fever, bronchial asthma) $)^{10,25}$.

\section{Lyonia ovalifolia}

Lyonia ovalifolia (anyaar or angeri) is a small deciduous tree growing up to $10 \mathrm{~m}$ tall found in the 1500 $3000 \mathrm{~m}$. (URL3). L.ovalifolia is a plant of ethnomedicinal relevance used for the treatment of wounds, cuts, burns, scabies etc, by different local communities of Nepal ${ }^{9,15}$. Some of the preliminary studies have suggested it's in vitro antibacterial activities ${ }^{19,21}$.

\section{Lichens}

The lichens (Jhoola ghas) are found in the entire Himalayas range. Jhoola ghas use bark, wood, rocks for growing. Jhulla Ghas is the non-timber forest product, obtained from the under oak species forest between April to September months ${ }^{12,13}$. Jhoola ghas is regularly used as a component of spices, dyes, Ayurvedic medicines, perfumes and other commercial purposes ${ }^{3,30}$.

\section{Quercus leucotriphora}

Quercus leucotrichophora (Banj oak) distribution altitude range is $1000-2500 \mathrm{~m}$ ams with high abundance around $1800-2200 m$ altitude $23,28,29,35$. This tree is an important component for the hill agroforestry system; it is directly linked with the livelihood of Himalayan people. In Uttarakhand, villagers and Tribals uses gum resin to cure Gonorrheal, asthma, haemorrhages, diarrhoea, dysentery, digestive disorders ${ }^{2,11}$.The seeds of the plant are used in the treatment of the urinary disorder ${ }^{22}$ and the bark of the plant $(25 \mathrm{~g}$ bark in $100 \mathrm{ml})$ in the form of gargle in tonsillitis ${ }^{11}$.

\section{Quercus semecarpifolia}

Quercus semecarpifolia (khasru and Brown oak) is a dominant species found in sub-alpine to the alpine forest of Himalayas ${ }^{22}$, found in the elevation range from 2100 to $3800 \mathrm{~m}$ above ams ${ }^{18}$. The commercial and ecological values of oak are generally higher than those of other species associated with oak. It is closely connected with hill agriculture as an important source of fodder for animals, litter for making compost, firewood and timber ${ }^{34}$.

\section{Toon ciliata}

Toon ciliata (tun and red cedar) ${ }^{7}$ is a medium-sized to a large deciduous tree found in the Shiwalik to a subHimalayan region. Flowers are used to producing dye and bark is useful in chronic dysentery, ulcer, leprosy, fever, headache ${ }^{7,16}$. The ethanolic leaf extract of T.ciliata has been studied for its inhibitive effects on protein nonenzymatic glycation ${ }^{7}$. The wood of T.ciliata is used in matchboxes, furniture and building materials ${ }^{20}$. 


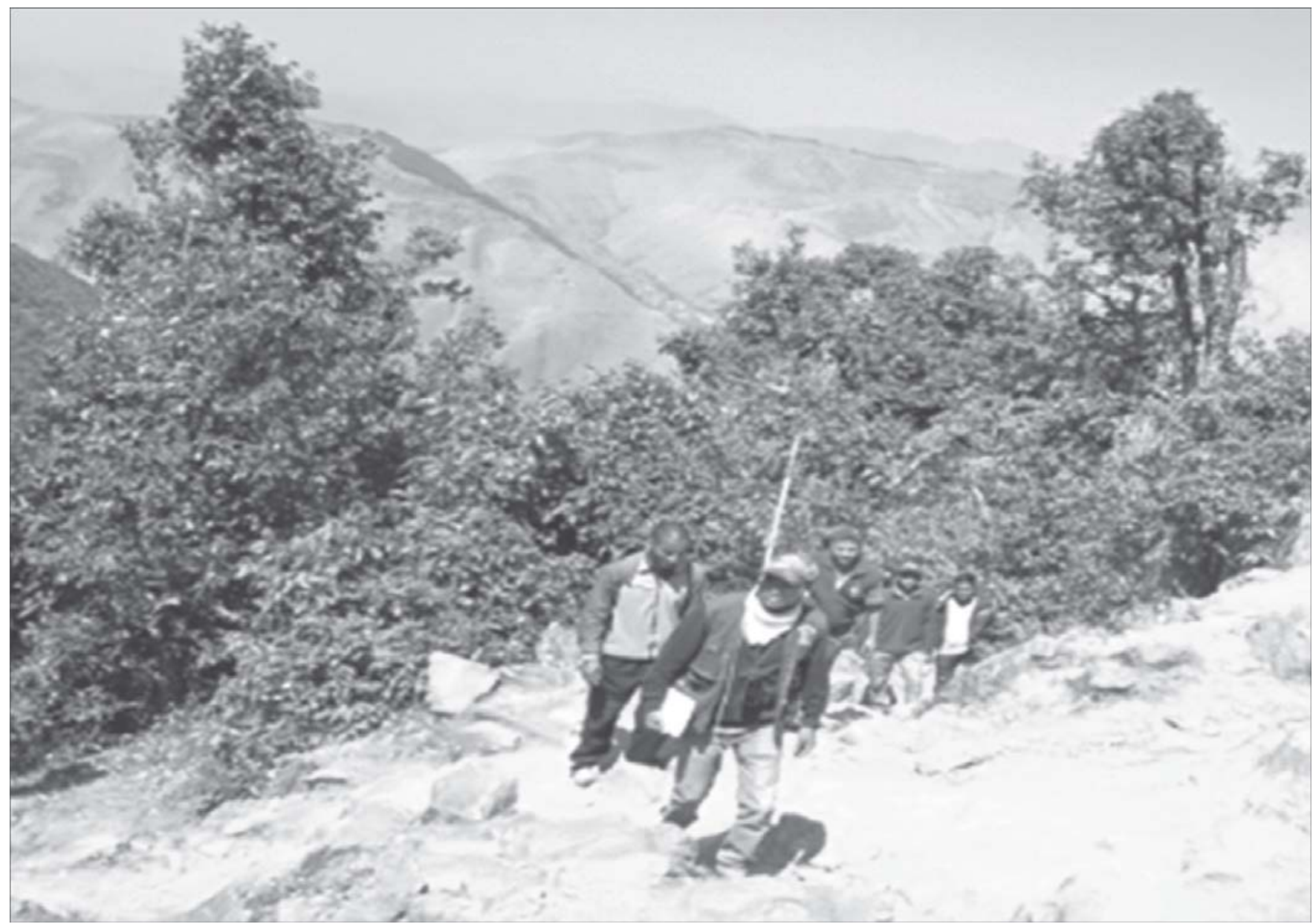

Fig. 3 : Trekking towards Nag Tibba

\section{Quercus floribunda}

Quercus floribunda (Moru or tilonj) is a large evergreen tree found in the Himalayan regions $^{31}$. Q.floribunda can grow upto 30 to $45 \mathrm{~m}$ with dense canopy cover and generally found in a scattered manner with other oak species and coniferous tree ${ }^{20}$. Q.floribunda wood is used for fuel and construction work, its leaves are also used as fodder for livestock ${ }^{20,22}$.

\section{Fauna}

Nag Tibba region coming under Tehri district which is the habitat of several species of wild animals, birds, and reptiles. In carnivorous, leopard (Panthera pardus) is chief predator in the regions and usually prey wild animallike, ghoral (Nemorhaedus goral), wild boar(Sus scrofa), Red Jungle fowl (Gallus gallus), rabbits and some time prey villager livestock, such as cow, bullocks, buffalo, sheep, goats and mules. Himalayan black bear (Ursus thibetanus) is found in oak forest and depend on fruits grains acorn of oaks and roots. Golden jackal (Canis aureus) prey small birds, jungle fowl, rabbits and small mammals. Wild boar live in the dense forest near the village but in the night reach to the agriculture field for food and destroy agriculture lands. The Ghoral
(Naemorhedus goral) a goat-like animal haunts in rocky hills within the forests between 1,200 to $2,500 \mathrm{~m}$ altitude, Ghoral usually lives in herds of 2 to 6 . Rhesus macaque monkey (Macaca mulatta) and Grey langurs (Semnopithecus entellus) found near the village area due to variety of food. According to altitudinal range Rhesus macaque restricts to $1200 \mathrm{~m}$ and Semnopithecus entellus found upto $3000 \mathrm{~m}$. (URL4).

\section{Reptiles}

Various types of reptiles species are seen in this region. In venomous species, spectacle cobra (Naja naja), Russell viper (Daboia russelii) observed below $2000 \mathrm{~m}$ and, above $2000 \mathrm{~m}$ hill snake (Ancistrodon himalayanus) are notified. In non-venomous snakes, python (Python molurus) and common rate snake (Ptyas mucosa) are easily notable. Leech (jonk) lives in oak forest with a moist environment and active in raining season. In amphibians species, frog and toads species easily seen in a moist place. (URL4).

\section{Birds}

Nag Tibba is the rich region for birds, found in separate elevation ranges. Red-billed blue magpie (Urocissa erythroryncha), Wild fowls, harials, parakeet, 


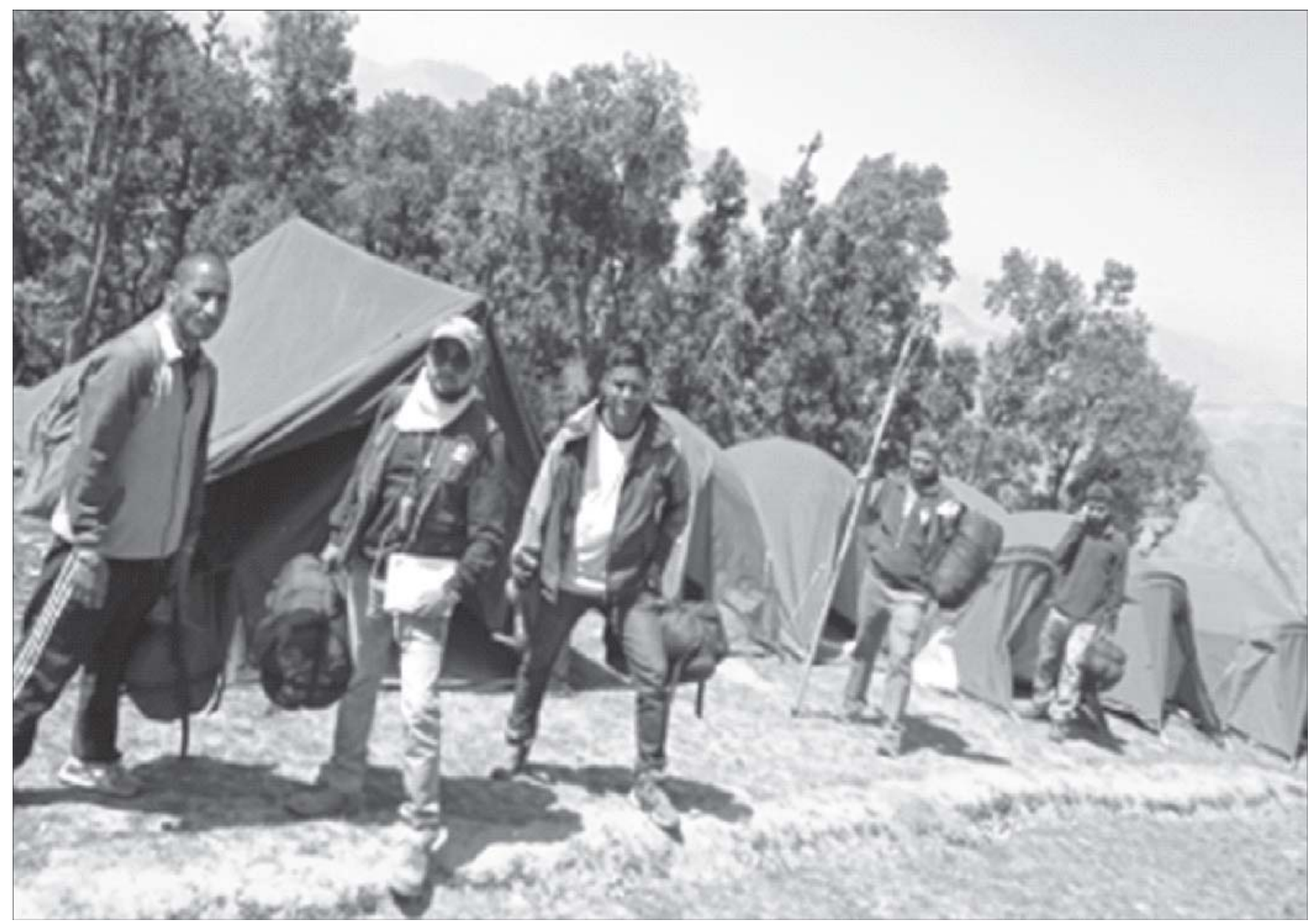

Fig. 4 : Camping site in Nag Tibba

pigeons, partridges and Indian Grey-Hornbill (Ocyceros birostris) are common in Nag Tibba region. Near the village area, some birds can regularly be observed such as magpies, jays, jungle babblers (Turdoides striata), laughing thrushes and woodpeckers. Among the partridges, the most popular is Kala titar (Francolinus francolinus) found upto $2,130 \mathrm{~m}$ and lives in shrub patches near cultivated land and frequently visit cultivated land to search for food. Among dove's species, spotted dove (Spilopelia chinensis) is very popular, found at heights of up to $3,000 \mathrm{~m}$. Out of the preying birds, vultures, falcons are also noticed (URL4).

\section{Cause of conservation}

\section{Organic and inorganic garbage}

Every year thousands of trekkers and tourists come in Nag Tibba for trekking and camping. They stay at the night, bring food along with them and sometimes cook food, but during trekking and after the end of camping, they leave behind different types of garbages, like plastic bags, liquor bottles, snacks wrappers in the camping site and treks also. Sometimes unfinished food (especially Non-veg) smell, attract the predators (top of Trophic level) to the camping site, which is dangerous to trekkers as well as a wild animal itself.

\section{Forest fires}

During camping in the night, visitors ignite bonfire for the entertainment and smoke cigarette, but sometimes forget to extinguish a live fire after the enjoyment and such fire flash spread in the forest with the help of wind, which causes a forest fire and Snacks wrappers (plastic bags) work as fuel for forest fire and burn for a long time compared to other forest organic matters.

\section{Noise Pollution}

Nowadays trekkers come in the groups, playing the songs very loudly via speakers and make the noise, which causes increase the noise pollution as well as terrifying the wildlife and gradually wildlife leaves the forest area. But the problem is more complicated because forest area around the Nag Tibba region is surrounded by the settlements and it's challenging for wildlife to cross such obstacles to reach un-disturbed forest area, even sometimes animals attack cattle \& villagers during migrating to another forest. For the leopards and wolfs, 


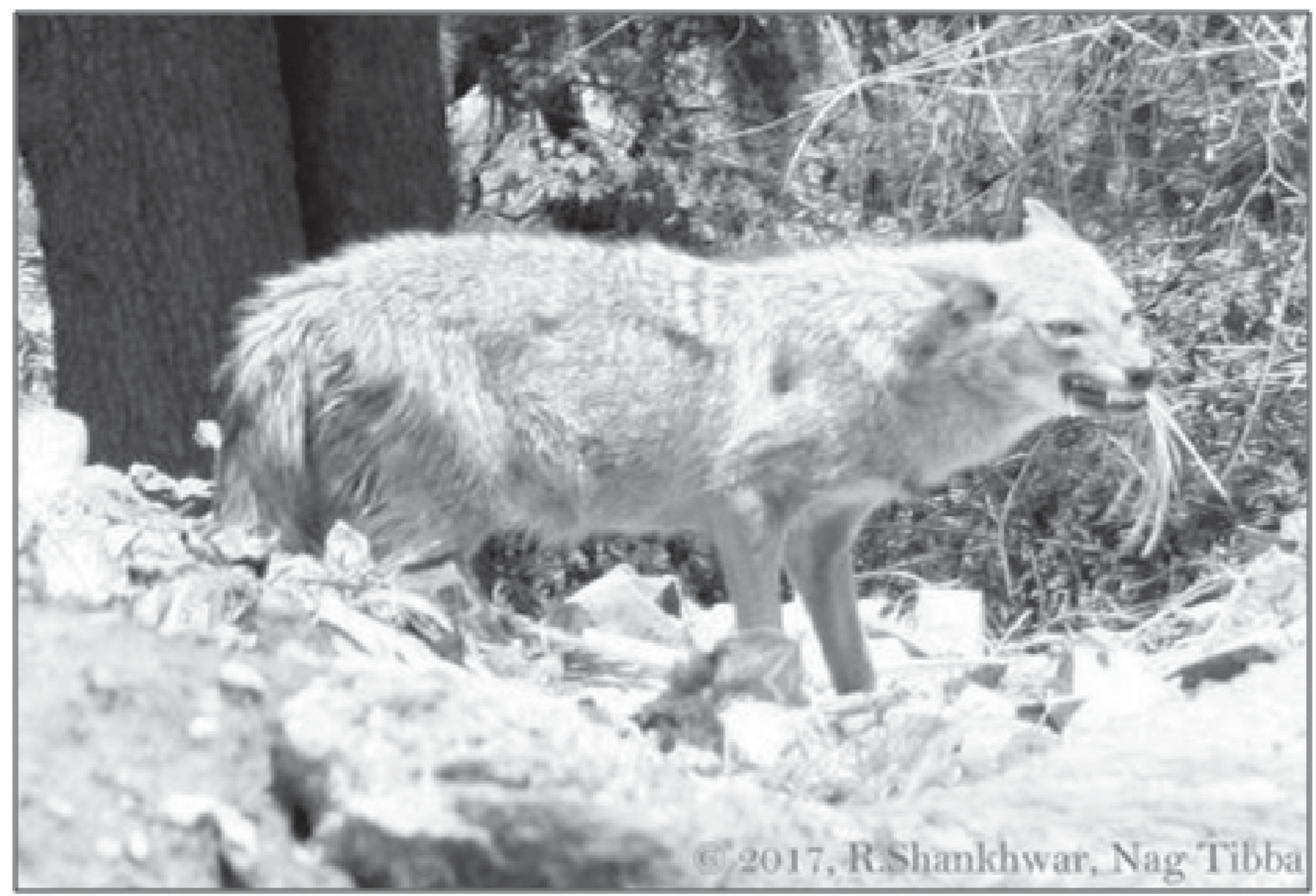

Fig. 5 : Golden jackal (Canis aureus) eating unfinished flesh threw by humans.

cattle and villagers appear quite obvious prey and gradually the frequency of attack increases. Ultimately it's very challenging for the wild animals as well as villagers to avoid this conflict. Sometimes people lay a trap for wild animals and spread live electric wire to guard their cattle or spread poisonous food nearby the village boundary so that wild animal cannot breach village border or agriculture fence.

\section{Grazing, Lopping, Collection of fuel wood and other biotic pressures}

Now a day's different forest tree species suffering from continuous pressure by livestock grazing, lopping, fuel wood and other biotic pressure, like banj oak (Quercus leucotrichophora) face heavy looping and poor regeneration which decline the acorn production and expansion alien invasive species ${ }^{27}$. Also cutting and burning of the oak tree have to lead to survive the invasion chir pine Pinus roxburghii. Quercus floribunda is generally lopped for fodder. The most important characteristics attribute of brown oak is poor seed viability and vivipary ${ }^{28}$, which impact regeneration of forest.

\section{Conclusions}

\section{Conservation of fauna and flora}

Leopard comes under the top of the food chain
(Trophic level-4) and if we protect leopards, then it's automatically creating the opportunity to sustain rest of trophic level (level 3 to1) organisms (Herbivores, Plants and algae). If we protect the superior animals of trophic level such as leopard and wolf, then we have to maintain the forest as well as increase the census of herbivorous because wild herbivorous is the main prey for the leopard and wolf and due to more carnivorous in the forest area, humans hesitate to go in the forest and gradually forest automatically restore the forest ecosystem and as a result of, wildlife come back to the forest area. Apart from this, the forest can also deliver numerous environmental advantages such as prevents soil erosion, enhance the rainwater infiltrates and restore the groundwater and help to sustain the productivity of the top layers of soil by leaf fall. The roots of the tree spread like a web beneath the earth surface and trap the soil and rocks, which prevent the occurrence of the landslide.

Use of LPG gas cylinder instead of fuel wood decreases the consumption of fuel wood collected from the forest and due to this reduces the rate of deforestation because deforestation leads the erosion of soil and transported by small streams, rivers and deposited in hydroelectricity reservoirs, which reduces the capacity 
Nag Tibba the Beauty trail of lesser Himalayas of Uttarakhand with special reference to fauna and flora conservation 09

and decrease the life of reservoirs.

Another advantage is to control the forest fire, which is mainly caused by anthropogenic activities like shepherds and trekkers smoke the cigarettes and threw in an unfinished condition and dry leaf of Chir pine tree easily catch the fire and spread in the forest area and soon entire forest area trap in the fire.
Limited activity and dependence of humans in the forest lead to restore the forest ecosystem itself and give a chance to survey fauna and flora because healthy forest not only maintains the local climate but also become the habitats of different types of fauna and flora. Healthy forest store the rainwater in their roots and supply water in a small stream and Dhara (small stream follow toward down from the rocks cracks and tree roots) throughout the year.

\section{References}

1. Chauhan NS. Medicinal \& aromatic plants of Himachal Pradesh. Indus Publishing Company, New Delhi. 1999 ; 353.

2. Chauhan PS, Bisht S, Ahmad S. Traditional and ethnobotanical uses of medicinal trees in district Tehri Garhwal Western Himalayas. Annals of Geriatric Education and Medical Sciences. 2016; 1(1):14-19.

3. Ding D. Oak moss and tree moss in China. Perfumer \& Flavorist. 1988; 13: pp. 13-16.

4. Forest Survey of India (FSI). Uttarakhand. In: India State of Forest Report 2011. Forest Survey of India (FSI), Dehradun, Uttarakhand, India. 2011; pp. 1-240.

5. Forest Survey of India (FSI). Uttarakhand. In: India State of Forest Report 2017. Forest Survey of India, Dehradun, Uttarakhand, India. 2017; pp. 1-367.

6. Gajendra Singh, Hitendra Padalia, Rai ID, Bharti RR, Rawat GS. Spatial extent and conservation status of Banj oak (Quercus leucotrichophora A. Camus) forests in Uttarakhand, Western Himalaya. Tropical Ecology. 2017; 57(2): 255-262, 2016 ISSN 0564-3295.

7. Hossain $\mathrm{H}$, et al. In-vivo anti-inflammatory and in-vitro antioxidant activities of Toona ciliata leaves native to Bangladesh. Global journal of medical research. 2014; 0975- 5888.

8. Joshi AR, Joshi K. Indigenous knowledge and uses of medicinal plants by local communities of the Kali Gandaki Watershed Area, Nepal. Journal of Ethnopharmacology. 2000; 73(1):175-83. DOI: 10.1016/S0378-8741(00)003019.

9. Joshi SR, Sharma S, Padalia H, Dadhwal VK. "Geospatial modeling of Kharsu Oak (Quercus semicarpifolia) distribution in Kumaun Himalaya under climate change scenarios. Journal of the Indian Society of Remote Sensing (in Press). 2010.

10. Kumar V, Suri S, Prasad R, Gat Y, Sangma C, Jakhu H, Sharma M. Bioactive compounds, health benefits and utilization of Rhododendron: a comprehensive review Agriculture \& Food Security. 2019; 8 : 6 https://doi.org/ 10.1186/s40066-019-0251-3.

11. Kumar M, Sheikh MA, Bussmann RW. Ethnomedicinal and ecological status of plants in Garhwal Himalaya, India. Journal of Ethnobiology and Ethnomedicine. 2011; 7(32):1-13.) doi: 10.1186/1746-4269-7-32.

12. Kumari P, Joshi GC, Tewari LM. Diversity and status of ethno-medicinal plants of Almora district in Uttarakhand, India. International Journal of Biodiversity and Conservation. 2011; 3(7):298-326).

13. Kumar B, Upreti DK. An account of lichens on fallen twigs of three Quercus species in Chopta forest of Garhwal Himalaya, India. Annals of Forestry.2008; 15(1): $92-98$.

14. Kumar M, Sharma CM, Rajwar GS. The effects of disturbance on forest structure and diversity at different altitudes in Grahwal Himalaya. Chinese Journal of Ecology. 2009; 28(3): 424-432.

15. Limbu DK. Indigenous knowledge of Limbu on Ecology, Biodiversity and Ethnomedicine. Lalitpur: SNV, Nepal. 2008.

16. Malairajan P, Kavimani S. Anti-ulcer activity of crude alcoholic extract of Toona ciliata Roemer (heartwood). ELSEVIER. Journal of Ethanopharmacology. 2007; 110: 348-351. https://doi.org/10.1016/j.jep.2006.10.018

17. Shah NC. Lichens of Commercial Importance in India 2014 the scitech journal issn 2347-7318. 1(2) : February 
2014).

18. Negi SS, Naithani HB. Oaks of India, Nepal and Bhutan. Dehradun: International Book Distributors. 1995.

19. Negi R, Negi YK, Uniyal V, Saxena S, Bisht S. Phytochemical Analysis and Antibacterial Activity of Three Indigenous Plants of Garhwal Himalaya against some Pathogenic Microorganisms. Journal of Pharmacy Research. 2012; 5(3): 1583- 1586.

20. Orwa C, Mutua A, Kindt R, Jamnadass R, Simons A. Agroforestree Database:a tree reference and selection guide version 4.0 (http://www.worldagroforestry.org/af/treedb/). 2009.

21. Panthi MP, Chaudhary RP. Antibacterial activity of some selected folklore medicinal plants from West Nepal. Scientific world. 2006; 4(4):16-21.

22. Rawat VS. Medicinal plants and sustainable livelihood in Pauri district of Garhwal Himalaya, Uttarakhand, India. International Journal of Bioassays. 2016; 5 : 4589-4592. ISSN: 2278-778X.

23. Rana BS, Singh SP, Singh RP. Biomass and net primary productivity in Central Himalayan forests along an altitudinal gradient. Forest Ecology and Management. 1989; 27: 199-218.

24. Rawat YS, Vishvakarma SCR. Pattern of fodder utilization in relation to sustainability under indigenous agroforestry systems, North-Western Himalaya, India. Environ. We Int. J. Sci. Tech. 2011; 6: 1-13.

25. Srivastava P. Rhododendron Arboreum: An Overview : Journal of Applied Pharmaceutical Science. 2012; 2 (1) : 158-162.

26. Saran S, Joshi R, Sharma S, Padalia H, Dadhwal VK. Geospatial modeling of Brown Oak (Quercus semecarpifolia) habitats in the Kumaun Himalaya under Climate Change scenario Journal of the Indian Society of Remote Sensing · September 2010; DOI: 10.1007/s12524-010-0038-2.

27. Singh JS, Singh SP. Forest of Himalaya; Structure, functioning and impact of man, Gyanodaya Prakashan, Nainital, India. 1992.

28. Singh JS, Singh SP. Structure and function of the Central Himalayan Oak forests. Proceeding of Indian National Science Academy (Plant Science). 1986; 96: 156-189.

29. Singh G, Rawat GS. Depletion of oak (Quercus spp.) forests in the western Himalaya Grazing, fuelwood and fodder collection. pp. 29-42. In: C. A. Okia (ed.) Global Perspectives on Sustainable Forest Management. InTech Publisher, Croatia. 2012.

30. Sochting U. Lichens of Bhutan. Biodiversity and use. Pub. University of Copenhagen, Botanical Institute, Dept. of Mycology. 1999; Pp. 1-30.

31. Tran G. Moru oak (Quercus floribunda). Feedipedia, a programme by INRA, CIRAD, AFZ and FAO. https:// www.feedipedia.org/node/110 Last updated on September 2016; $10: 21$.

32. Troup RS. The silviculture of Indian trees Clarendon Press, Oxford, UK. 1921; 1195p.

33. Upreti N, Tewari JC, Singh SP. The oak forests of Kumaun Himalaya (India): Composition, Diversity, and regeneration. Mountain Research and Development. 1985; 5:163-174.

34. Valdia KS. Dynamic Himalaya. Haidarabad: University Press Ltd. 1998; 178 p.

35. Zobel BD, Singh SP. Himalayan forests and ecological generalizations. Bio Science. 1997; 47 : 735-745. 